\title{
Inhibition of Insulin-Stimulated Xylose Uptake in Rat Soleus Muscle by Cycloheximide
}

\author{
J.R. Forsayeth and M.K. Gould \\ Department of Biochemistry, Monash University, Clayton, Victoria, Australia
}

\begin{abstract}
Summary. Cycloheximide (20-200 mg/l) did not affect basal

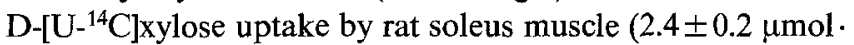
$\mathrm{g}^{-1} \cdot \mathrm{h}^{-1}$ ). However, the stimulatory effect of insulin on sugar transport was progressively reduced from $375 \%$ above basal in control muscles to $170 \%$ in muscles exposed to $200 \mathrm{mg}$ cycloheximide/ 1 but above this concentration cycloheximide inhibited basal xylose uptake without further effect on the incremental effect of insulin. Cycloheximide affected the insulin dose-response curve both by depressing insulin sensitivity and by reducing the maximum stimulatory effect of the hormone. In contrast to the inhibition of insulin action, which increased progressively over the range $20-200 \mathrm{mg}$ cycloheximide/l,
\end{abstract}

muscle protein synthesis was inhibited maximally at a concentration of $10 \mathrm{mg} / 1$. Cycloheximide also inhibited the insulinomimetic effects of anoxia, 2:4-dinitrophenol, salicylate, cooling, hydrogen peroxide, diamide, vitamin $\mathrm{K}_{5}$, hyperosmolarity and EDTA, but did not affect concanavalin A-stimulated xylose uptake. It is concluded that cycloheximide inhibits insulin-stimulated sugar transport at some late post-receptor step, and that this effect of cycloheximide is not secondary to the inhibition of protein synthesis.

Key words: Sugar transport, insulin, cycloheximide, concanavalin $\mathrm{A}$.
The overall process whereby insulin stimulates glucose transport in muscle and adipose tissue can be considered in three phases: (a) the initial interaction of the hormone with its receptor, (b) the signalling mechanism between the receptor and the glucose carrier, and (c) activation of the carrier itself. During the last decade the structure and function of the insulin receptor has been studied extensively $[1,2]$. More recently, it has been suggested that activation of glucose transport involves the translocation of sugar carriers from intracellular sites to the plasma membrane $[3,4]$. However, the nature of the signal which links the receptor to the glucose transport system has yet to be defined. Insulin promotes the release of a chemical mediator from the plasma membrane, which appears to mediate the effect of the hormone intracellularly on glycogen synthase and pyruvate dehydrogenase [5-7]. As yet this mediator has not been associated with insulin-stimulated sugar transport.

One aproach to the study of the coupling system is the use of agents which inhibit insulin action at the post-receptor level. Previous reports from this laboratory have described the effects of two such agents, denervation [8] and the divalent cation ionophore, A 23187 [9], on insulin-stimulated sugar transport in soleus muscle. Yu \& Gould [10] observed that the protein synthesis in- hibitor, cycloheximide, also blocked insulin-stimulated sugar transport post-receptorally; thus, cycloheximide inhibited insulin action but did not affect ${ }^{125} \mathrm{I}$-insulin binding. In this paper we present the results of further studies concerning the nature of the inhibitory effect of cycloheximide on sugar transport in soleus muscle.

\section{Materials and Methods}

Soleus muscles weighing approximately $30 \mathrm{mg}$ were removed from Sprague-Dawley rats $(70-90 \mathrm{~g})$ fed ad libitum. Muscles were incubated at $37^{\circ} \mathrm{C}$ under an atmosphere of $\mathrm{O}_{2}-\mathrm{CO}_{2}(95: 5, \mathrm{v} / \mathrm{v})$; anaerobic incubations were under $\mathrm{N}_{2}-\mathrm{CO}_{2}(95: 5, \mathrm{v} / \mathrm{v})$. The basic ('bicarbonate') medium contained $\mathrm{NaCl}(118 \mathrm{mmol} / 1), \mathrm{KCl}(4.8 \mathrm{mmol} / 1), \mathrm{CaCl}_{2}$ $(2.6 \mathrm{mmol} / \mathrm{l}), \quad \mathrm{MgSO}_{4}(1.2 \mathrm{mmol} / \mathrm{l}), \mathrm{KH}_{2} \mathrm{PO}_{4}(1.2 \mathrm{mmol} / \mathrm{l})$ and $\mathrm{NaHCO}_{3}(25 \mathrm{mmol} / 1)$; before use the medium was gassed with the appropriate gas mixture. Variations from this basic medium are detailed in the text.

\section{Sugar Transport}

Soleus muscles were first pre-incubated under the test conditions, xylose uptake was then determined using the method of Korbl et al. [11]. Briefly, this procedure measures intracellular xylose as the difference between the distribution of D-xylose and the extracellular marker, D-sorbitol. Muscles were incubated for $5 \mathrm{~min}$ at $37^{\circ} \mathrm{C}$ in bicar- 
Table 1. Effect of cycloheximide on activators of muscle sugar transport

\begin{tabular}{|c|c|c|c|c|c|}
\hline Activator & $\begin{array}{l}\text { Period of exposure to } \\
\text { activator (min) }\end{array}$ & \multicolumn{2}{|c|}{ Xylose uptake $\left(\mu \mathrm{mol} \cdot \mathrm{g}^{-1} \cdot \mathrm{h}^{-1}\right)$} & $\begin{array}{l}\text { Inhibition } \\
(\%)^{*}\end{array}$ & $p$ \\
\hline $2:$ 4-dinitrophenol $(0.5 \mathrm{mmol} / 1)$ & 10 & $7.0 \pm 0.3$ & $3.8 \pm 0.2$ & 70 & $<0.005$ \\
\hline Salicylate $(20 \mathrm{mmol} / 1)$ & 30 & $7.6 \pm 0.6$ & $4.8 \pm 0.5$ & 54 & $<0.001$ \\
\hline Cooling & $180^{\mathrm{b}}$ & $7.9 \pm 0.8$ & $5.5 \pm 0.4$ & 44 & $<0.01$ \\
\hline Vitamin $\mathrm{K}_{5}(0.05 \mathrm{mmol} / 1)$ & 30 & $7.4 \pm 0.4$ & $5.6 \pm 0.3$ & 36 & $<0.01$ \\
\hline Concanavalin A $(500 \mathrm{mg} / \mathrm{l})$ & 30 & $6.5 \pm 0.3$ & $6.1 \pm 0.2$ & 10 & $<0.30$ \\
\hline Mannitol $(200 \mathrm{mmol} / 1)$ & 30 & $7.7 \pm 0.4$ & $6.0 \pm 0.3$ & 32 & $<0.005$ \\
\hline EDTA $(5 \mathrm{mmol} / \mathrm{l})$ & $5^{c}$ & $7.7 \pm 0.4$ & $6.4 \pm 0.3$ & 25 & $<0.02$ \\
\hline
\end{tabular}

Except as noted below, soleus muscle pairs were incubated for $30 \mathrm{~min}$ at $37^{\circ} \mathrm{C}$ under aerobic conditions \pm cycloheximide $(200 \mathrm{mg} / 1)$. The agents shown were then added and the incubations continued for the times shown in the second column. Values are mean $\pm S E M$ of five determinations: (a) Muscles were incubated for $60 \mathrm{~min}$ at $37^{\circ} \mathrm{C}$ under $95 \% \mathrm{~N}_{2}: 5 \% \mathrm{CO}_{2}$; (b) After $30 \mathrm{~min}$ at $37^{\circ} \mathrm{C}$, muscles were incubated for $180 \mathrm{~min}$ at $0{ }^{\circ} \mathrm{C}$; $\mathrm{xy}-$ lose uptake was determined at $37^{\circ} \mathrm{C}$; (c) The bicarbonate medium was modified by the omission of $\mathrm{Ca}^{2+}$ and $\mathrm{Mg}^{2+}$.

* calculated on the basis of the incremental stimulation above basal xylose uptake $\left(2.4 \pm 0.2 \mu \mathrm{mol} \cdot \mathrm{g}^{-1} \cdot \mathrm{h}^{-1}\right)$

bonate medium $(0.5 \mathrm{ml})$ containing $\mathrm{D}$-[U. $\left.{ }^{14} \mathrm{C}\right] \mathrm{xylose}(10 \mathrm{mmol} / \mathrm{l}$, spec. act. $0.03 \mu \mathrm{Ci} / \mu \mathrm{mol})$ and $\mathrm{D}-\left[1-{ }^{3} \mathrm{H}\right]$ sorbitol $(10 \mathrm{mmol} / 1$, spec, act. $0.1 \mu \mathrm{Ci} / \mu \mathrm{mol})$. Muscles were solubilized by heating for $2 \mathrm{~h}$ at $50^{\circ} \mathrm{C}$ in NCS tissue solubilizer $(0.5 \mathrm{ml})$; radioactivity was determined by counting in the presence of a toluene scintillator solution.

\section{Protein Synthesis}

Muscles were incubated for $15 \mathrm{~min}$ at $37^{\circ} \mathrm{C}$ in bicarbonate medium containing L-[U- $\left.{ }^{14} \mathrm{C}\right]$ leucine $(1 \mathrm{mmol} / 1$, spec. act. $1 \mu \mathrm{Ci} / \mu \mathrm{mol})$, then rinsed briefly in ice-cold water and homogenized in trichloroacetic acid $(1 \mathrm{ml}, 100 \mathrm{~g} / \mathrm{l})$. The homogenizer was rinsed twice, each with $1 \mathrm{ml}$ of trichloroacetic acid $(100 \mathrm{~g} / 1)$; the combined homogenate and rinsings were heated for $5 \mathrm{~min}$ at $100^{\circ} \mathrm{C}$, cooled in ice and filtered through a $2.1 \mathrm{~cm}$ Whatman GF/A glass filter disc in a Millipore filter. The precipitate on the filter was washed three times each with $5 \mathrm{ml}$ of ice-cold L-leucine $(10 \mathrm{mmol} / 1)$ in trichloroacetic acid $(50 \mathrm{~g} / \mathrm{l})$ then three times each with $1 \mathrm{ml}$ of absolute ethanol and then dried for $2 \mathrm{~min}$ at $110^{\circ} \mathrm{C}$. The filter discs were placed into counting vials with $1 \mathrm{ml}$ of NCS tissue solubilizer and the precipitate dissolved by heating for $2 \mathrm{~h}$ at $50^{\circ} \mathrm{C}$. Toluene scintillator $(10 \mathrm{ml})$ was added and the radioactivity counted.

\section{Materials}

D-[U- $\left.{ }^{14} \mathrm{C}\right] \mathrm{xyl}$ lose, $\mathrm{L}-\left[\mathrm{U}-{ }^{14} \mathrm{C}\right] \mathrm{leucine}$ and NCS tissue solubilizer were from Amersham (Australia) Sydney. D $\left[1-{ }^{3} \mathrm{H}\right]$ sorbitol was from New England Nuclear Corporation, Boston. Beef insulin, twice recrystallized, was from the Commonwealth Serum Laboratories, Melbourne. 2:4-dinitrophenol and EDTA were from British Drug House Chemicals (Australia) Sydney. Concanavalin A was from Boehringer-Mannheim (Australia), Sydney. Cycloheximide and mannitol were from Calbiochem-Behring (Australia), Sydney. Vitamin $\mathrm{K}_{5}$ was from Tokyo Kasei Kogyo, Tokyo. Diamide was from Sigma Chemicals, St. Louis, Mo. USA.

\section{Statistical Analysis}

To minimise the effect of biological variation between individual animals, wherever possible the experiments were designed using paired controls. One muscle from each pair was incubated under test conditions, while the second served as the control. The results of these experiments were analyzed for statistical significance using Student's t-test as applied to paired samples. Where it was not possible to use paired controls, muscles taken from litter mates were distributed randomly among the experimental groups and the results subjected to statistical analysis using the standard Student's t-test.

\section{Results}

Soleus muscles were exposed to cycloheximide (20$1000 \mathrm{mg} / \mathrm{l}$ ) for $60 \mathrm{~min}$ in the presence and absence of insulin $(100 \mathrm{U} / \mathrm{l})$. Insulin-stimulated xylose uptake was inhibited by cycloheximide over the range $20-200 \mathrm{mg} / 1$ (Fig.1). When the cycloheximide concentration was increased beyond $200 \mathrm{mg} / 1$, xylose uptake in insulintreated muscles was depressed further; however, this seems to be related to the effect of the inhibitor on basal sugar transport, as the incremental stimulation by insulin was unchanged over the range $200-1000 \mathrm{mg} / 1$. To avoid any complications associated with the inhibition of basal sugar transport, a concentration of $200 \mathrm{mg}$ cycloheximide/ 1 was used for subsequent experiments.

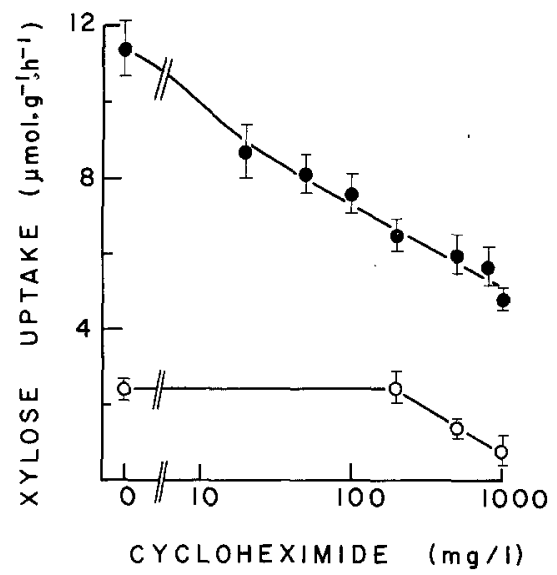

Fig. 1. Inhibition of insulin-stimulated xylose uptake by cycloheximide. Soleus muscle pairs were incubated for $60 \mathrm{~min}$ at $37^{\circ} \mathrm{C}$ in bicarbonate medium \pm insulin $(100 \mathrm{U} / 1)$ in the presence of cycloheximide $(0-1000 \mathrm{mg} / 1)$. Values are mean \pm SEM of five determinations; $\longrightarrow$, in the presence of insulin, $\bigcirc$ 

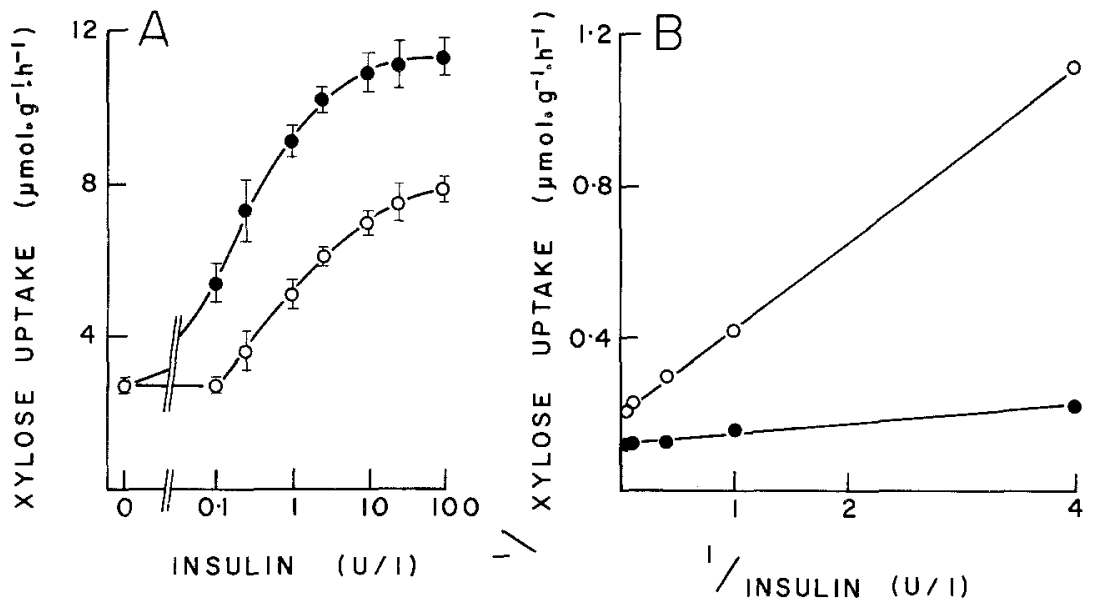

Fig. 2 A and B. Effect of cycloheximide on insulin sensitivity. A Soleus muscle pairs were incubated for $60 \mathrm{~min}$ at $37^{\circ} \mathrm{C} \pm$ cycloheximide $(200 \mathrm{mg} / 1)$; insulin $(0-100 \mathrm{U} / \mathrm{l})$ was added $15 \mathrm{~min}$ before the end of the incubation period. Values are mean \pm SEM of five determinations; $\mathrm{O}-\mathrm{O}$, in the presence of cycloheximide without cycloheximide B Double reciprocal plot of the data shown in Figure $2 \mathrm{~A}$. Incremental insulin stimulation was calculated as the difference between xylose uptake measured in the presence and absence of insulin

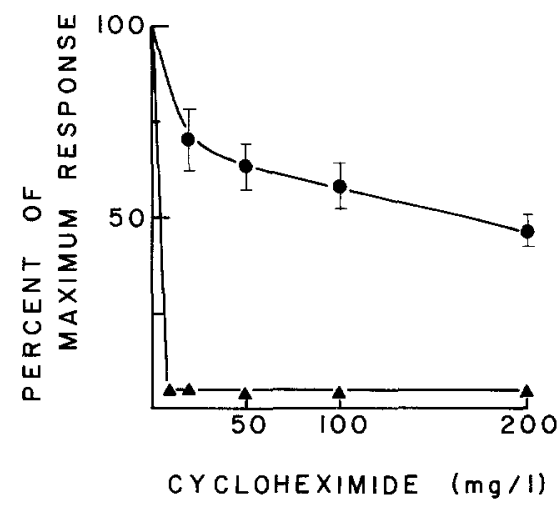

Fig. 3. Effect of cycloheximide on protein synthesis by soleus muscle $\triangle \sim$. Soleus muscles incubated for $60 \mathrm{~min}$ at $37^{\circ} \mathrm{C}$ in the presence of cycloheximide $(0-200 \mathrm{mg} / 1) \cdot\left[\mathrm{U}-{ }^{14} \mathrm{C}\right]$ leucine $(1 \mathrm{mmol} / 1$, spec. act. $1 \mu \mathrm{Ci} / \mu \mathrm{mol}$ ) was added $15 \mathrm{~min}$ before the end of the incubation period. Values are mean $\pm S E M$ of five determinations. Insulin-stimulated xylose uptake values $(\longrightarrow$ ) are from Figure 1.

The effect of cycloheximide on the insulin-sensitivity curve was examined over the range $0-100 \mathrm{U}$ insulin $/ 1$. The results presented in Figure $2 \mathrm{~A}$ show that cycloheximide reduced insulin-sensitivity; the inhibitor also seemed to lower the maximum response to the hormone. To obtain an objective (although not necessarily unbiased) estimate of the maximum response, the data from Figure $2 \mathrm{~A}$ was replotted in the form of the double reciprocal plot (Figure 2B), from which the maximum rates of xylose uptake in insulin-treated muscles were calculated to be $11.0 \mu \mathrm{mol} \cdot \mathrm{g}^{-1} \cdot \mathrm{h}^{-1}$ for control muscles and $7.7 \mu \mathrm{mol} \cdot \mathrm{g}^{-1} \cdot \mathrm{h}^{-1}$ for muscles exposed to cycloheximide. Furthermore, the concentration of insulin required to stimulate sugar transport by $50 \%$ was increased fivefold, from $0.2 \mathrm{U} / 1$ in control muscles to $1.1 \mathrm{U} / 1$ in cycloheximide-treated muscles.

Since cycloheximide is a potent inhibitor of protein synthesis, it is pertinent to ask whether its effect on insulin-stimulated sugar transport is secondary to the inhibition of muscle protein synthesis. The effects of cycloheximide on insulin-stimulated xylose uptake and on the incorporation of $\mathrm{L}-\left[\mathrm{U}-{ }^{14} \mathrm{C}\right]$ leucine into muscle protein are compared in Figure 3. Protein synthesis was in- hibited $96 \%$ when muscles were treated with cycloheximide $(10 \mathrm{mg} / 1)$; there was no further effect on protein synthesis above this concentration of cycloheximide. In contrast, the effect of the inhibitor on insulin action increased progressively over the range $20-200 \mathrm{mg} / 1$.

To define the nature of the inhibitory effect of cycloheximide more precisely, we examined the effect of this inhibitor on the action of a number of other agents which have been shown to stimulate sugar transport in muscle: anoxia, 2:4-dinitrophenol, salicylate, cooling, hyperosmolarity ( $200 \mathrm{mmol}$ mannitol/1), EDTA, $\mathrm{H}_{2} \mathrm{O}_{2}$, diamide, vitamin $\mathrm{K}_{5}$ and concanavalin $\mathrm{A}[8,11]$. Cycloheximide $(200 \mathrm{mg} / 1)$ inhibited the stimulatory effects of all these agents with the sole exception of concanavalin A (Table 1). The inhibitory action of cycloheximide, calculated in terms of inhibition of the incremental effects of these agents over basal xylose uptake, varied from $15 \%$ inhibition (diamide) to $70 \%$ inhibition (2:4-dinitrophenol); by comparison, in the experiments shown in Figures 1 and 2, cycloheximide $(200 \mathrm{mg} / 1)$ inhibited insulin-stimulated xylose uptake by $40-54 \%$.

\section{Discussion}

During the course of studying the ATP-dependence of insulin-stimulated sugar transport in rat soleus muscle, Yu and Gould [10] observed that cycloheximide, a potent inhibitor of protein synthesis, also inhibited insulin-stimulated xylose uptake. Because it does not inhibit ${ }^{125}$ I-insulin binding by soleus muscle, cycloheximide has the potential for use as a metabolic probe to study insulin action at the post-receptor level. We have confirmed that cycloheximide does not affect ${ }^{125}$ I-insulin binding by soleus muscle, even at inhibitor concentrations as high as $1000 \mathrm{mg} / \mathrm{I}$ (J.R. Forsayeth, unpublished data). Up to a concentration of $200 \mathrm{mg} / 1$, the inhibitory action of cycloheximide was restricted to insulin-stimulated sugar transport; above this concentration sugar transport was affected also.

It is now apparent that not all the effects of protein synthesis inhibitors on cellular metabolism are due to 
the inhibition of protein synthesis [12-16]. On the basis of differences between the effects of cycloheximide and puromycin and because of the rapidity with which cycloheximide inhibited insulin-stimulated xylose uptake, $\mathrm{Yu}$ and Gould [10] concluded that this effect was not secondary to the inhibition of protein synthesis. We have found that higher concentrations of cycloheximide are required to inhibit insulin-stimulated xylose uptake than are needed to block completely that portion of protein synthesis which is sensitive to this inhibitor ( $96 \%$ of total). This observation is further evidence that the insulin-antagonistic effect of cycloheximide is independent of the inhibition of protein synthesis.

In contrast to the action of denervation, which had little effect on other insulinomimetic agents apart from insulin, cycloheximide inhibited the action of 9 of the 10 agents tested (Table 1), which places the site of action of this inhibitor closer to the glucose carrier than denervation. Three of the agents, anoxia, 2:4-dinitrophenol and salicylate, are believed to stimulate muscle sugar transport as a consequence of their lowering of ATP levels [11]. The effect of these three agents has been linked to that of cooling [17]. The inhibitory effect of cycloheximide on the action of these four agents (44-70\% inhibition) was greater than on the other insulinomimetic agents (15-36\% inhibition). Whether or not this apparent difference has significance in terms of the action of these various agents remains to be seen.

The only agent which appeared to be insensitive to inhibition by cycloheximide was concanavalin $\mathrm{A}$. This finding is paralleled by the observation of Yasmeen et al. [13] that puromycin inhibited convanavalin A-stimulated sugar transport in thymocytes, but cycloheximide did not. Concanavalin $\mathrm{A}$ is one of a series of plant lectins which stimulate glucose transport in adipocytes [18, 19]. It has been suggested that the insulinomimetic action of concanavalin A could result from the binding of the lectin to the insulin receptor, thus provoking the release of the 'insulin' signal [20]. However, its insensitivity to cycloheximide, in contrast to the sensitivity of insulin and the other agents tested, suggests that its action cannot be concerned with the insulin receptor. Previous experiments, which showed that the effect of concanavalin $\mathrm{A}$ on muscle sugar transport was not attenuated by denervation, prompted a similar conclusion [8]. The present result modifies this observation by suggesting that the action of concanavalin $\mathrm{A}$ is localized at some point much closer to the carrier system, beyond the site of action of cycloheximide.

\section{References}

1. Gliemann J, Laursen AL, Foley JE, Sonne O (1981) The insulin receptors: looking at the present. In: Andreani D, DePirro R, Lauro R, Olefsky J, Roth J (eds) Serono Symposium No.41. Current views on insulin receptors. Academic Press, London New York, pp 1-12

2. Czech MP, Massague J (1982) Subunit structure and dynamics of the insulin receptor. Fed Proc 41:2719-2723
3. Karnieli E, Zarnowski MJ, Hissin PJ, Simpson IA, Salans LB, Cushman SW (1981) Insulin-stimulated translocation of glucose transport systems in the isolated rat adipose cell. Time course, reversal, insulin concentration dependency, and relationship to glucose transport activity. J Biol Chem 256: 4772-4777

4. Kono T, Suzuki K, Dansey LE, Robinson FW, Blevins TL (1981) Energy-dependent and protein-synthesis-independent recycling of the insulin-sensitive glucose transport mechanism in fat cells. J Biol Chem 256: 6400-6407

5. Larner J, Cheng K, Schwartz C, Kikuchi K, Tamura S, Creacy S, Dubler R, Galasko G, Pullin C, Katz M (1982) A proteolytic mechanism for the action of insulin via oligopeptide mediator formation. Fed Proc 41: 2724-2729

6. Seals JR, Czech MP (1982) Production by plasma membranes of a chemical mediator of insulin action. Fed Proc 41: 2730-2735

7. Jarett L, Kiechle FL, Parker JC (1982) Chemical mediator or mediators of insulin action: response to insulin and mode of action. Fed Proc 41: 2736-2741

8. Forsayeth JR, Gould MK (1982) Inhibition of insulin-stimulated xylose uptake in denervated rat soleus muscle: a post-receptor effect. Diabetologia 23: 511-516

9. Hall S, Keo L, Yu KT, Gould MK (1982) Effect of ionophore A 23187 on basal and insulin-stimulated sugar transport by rat soleus muscle. Diabetes 31: 846-850

10. Yu KT, Gould MK (1979) Effect of protein synthesis inhibitors on xylose uptake and ${ }^{125} \mathrm{I}$-insulin binding by rat soleus muscle. Biochem Biophys Res Commun 87:9-16

11. Korbl GP, Sloan IG, Gould MK (1977) Effect of anoxia, 2:4-dinitrophenol and salicylate on xylose transport by isolated rat soleus muscle. Biochim Biophys Acta 465: 93-109

12. Sovik $O$ (1966) Effect of puromycin and puromycin analogues on glycogen synthesis in the isolated rat diaphragm. Acta Physiol Scand 66:307-315

13. Yasmeen D, Laird AJ, Hume DA, Weidemann MJ (1977) Activation of 3-0-methyl-glucose transport in rat thymus lymphocytes by concanavalin A. Temperature and calcium ion dependence and sensitivity to puromycin but not to cycloheximide. Biochim Biophys Acta 500: 89-102

14. Garber AJ, Jomain-Baum M, Salganicoff L, Farber E, Hanson RW (1973) The effect of cycloheximide on energy transfer in rat and guinea pig liver mitochondria. J Biol Chem 248: 1530-1535

15. Wititsuwannakul D, Kim KH (1977) Effect of cycloheximide on adenosine $3^{\prime}: 5^{\prime}$-monophosphate level in rat epididymal fat tissue. Biochem Biophys Res Commun 76: 86-92

16. Huerta-Bahena J, Villalobos-Molina R, Garcia-Sainz JA (1982) Cycloheximide: an adrenergic agent. Life Sci 30: 1757-1762

17. Yu KT, Gould MK (1981) Stimulation of sugar transport in rat soleus muscle by prolonged cooling at $0^{\circ} \mathrm{C}$. Diabetologia 21 : 482-488

18. Czech MP, Lynn WS (1973) Stimulation of glucose metabolism by lectins in isolated white fat cells. Biochim Biophys Acta 297: $368-377$

19. Czech MP, Lawrence JC, Lynn WS (1974) Activation of hexose transport by concanavalin $A$ in isolated brown fat cells. Effects of cell surface modification with neuraminidase and trypsin on lectin and insulin action. J Biol Chem 249: 7499-7505

20. Cuatrecasas P (1973) Interaction of concanavalin A and wheat germ agglutinin with the insulin receptor of fat cells and liver. J Biol Chem 248: 3528-3534

Received: 18 April 1983

and in revised form: 7 July 1983

Dr. M. K. Gould

Department of Biochemistry

Monash University

Clayton

Victoria 3168

Australia 